FedUni ResearchOnline

http://researchonline.federation.edu.au

This is an Accepted Manuscript of an article published by Taylor \& Francis in Regional Studies on 15/05/2015, available online: 


\section{Economic Resilience of Regions under Crises: A Study of the Australian Economy}

\section{Introduction}

Resilience is about addressing vulnerability, not only by surviving a shock to the system under investigation, but also for the system to thrive in an environment of change and uncertainty. Recent severe economic and ecological crises raise questions about sustainable development and resilience of regions within different industries (COURVISANOS, 2012). A robust conceptual model is required to navigate through these underlining elements of vulnerability. The robustness of such a model depends on traversing mere calculable risk assessments and addressing fundamentally incalculable uncertainty in a way that manages to incorporate all forms of unknown "Black Swan events". Such events are unplanned and unpredictable surprise occurrences (or shocks) that can change the course of economic and social activity (TALEB, 2007). NORRIS et al. (2008, p. 132) warn that “...these surprises are nearly impossible to predict or prepare for, and thus call for broad resilience strategies.”

A conceptual economic resilience model is developed based on an evolutionary approach and then applied to a study of the 558 local government areas (LGAs) in Australia. To make the study coherent and manageable, these LGAs have been divided into four distinct functional groups of regions using the classification first set up by NATIONAL ECONOMICS (2002) metropolitan core (Metro-Core), metropolitan peripheral (Metro-Periphery), regional cities (Regional Cities) and rural areas (Rural). The research question can be stated: What is the nature of resilience within the four functional groups of regions with respect to their industries as identified in the Local Government Areas of Australia, when evaluated longitudinally over a period of significant crises?

The concept of resilience has attracted academic attention in the regional economics literature since 2008 (BRISTOW, 2010; BRISTOW and HEALY, 2013; CELLINI and TORRISI, 
2014; CHAPPLE and LESTER, 2010; FINGLETON et al., 2012; HOLM and ØSTERGAARD, 2013; PENDALL et al., 2008; PIKE et al., 2010; TREADO, 2010), yet the adaptive ability of regions to generate income and be resilient in the context of crises is not well understood. SIMMIE and MARTIN (2010) provide an evolutionary model that enables resilience against crises to be investigated. It is this model that is adapted into a framework for examination of Australian regions and industries, and their income generation capability during cycles and crises.

Analysis of Australia and the resilience of all its regions and its respective industries is a unique country-wide perspective in theory and application. Australia is usually ignored in the literature which generally focuses on the advanced economies of North America and Western Europe. As with other advanced economies, Australia is characterised by gradual loss of manufacturing and increasing reliance on mining and service industries. The Australian economy is based on a strong export based primary sector, exposed by fluctuations in commodity prices. It is also underpinned by significant foreign direct investment in both these sectors and across this small open economy. The vagaries of the international economic environment coupled with public sector austerity, cyclical floods and droughts, and a volatile currency, play havoc with the Australian economy (HENRY, 2013; LIM et al., 2014). Therefore, the resilience of regions in the context of this national economic environment is worth evaluating and studying in its own right as an advanced economy commodity producer.

From the evolutionary perspective, this study evaluates economic resilience across four LGA regional functional groups in Australia, their institutions and industries, with longitudinal data from the Australian Bureau of Statistics (ABS) (ABS 2001a; 2001b; 2006a; 2006b; 2011a; 2011b) for the period 2001-2011. Data for these periods were retrieved from the ABS Census of Population and Housing, and the relevant data sets for the analysis were generated using the ABS TableBuilder function. The analysis conducted uses extensive ABS census 
data to identify regional functional groups, their industries and their economic resilience. The study applies $k$-means cluster analysis, an approach thus far not used in the evaluation of resilience. This cluster analysis is able to apply measures of employment and income change over time to find associations between industries and regions in a rigorous statistical manner. All 558 LGAs in Australia are evaluated for their reaction to endogenous shock (the Global Financial Crisis) (WETTENHALL, 2011) and exogenous shock (drought) (EDWARDS et al., 2009; HORRIDGE et al., 2005). This research uses measures of employment and income change over time to appreciate the nature of resilience in relation to regions and their industries. This understanding occurs by providing an overall macroeconomic picture of resilience across the entire country and all industries. Resilience is categorised over this specified period in conjunction with the regional geography of LGAs.

\section{Regional Economic Resilience: Definition}

SIMMIE and MARTIN (2010, p. 28) describe regional economic resilience in terms of “adaptive ability”, in which there is “...the differential ability of a region’s or locality’s firms to adapt to changes and shocks in competitive, market, technological, policy and related conditions that shape the evolutionary dynamics and trajectories of that regional or local economy over time”. In the context of regional economies, dynamic resilience means the ability of the regional economy not just to recover after an economic or ecological downturn, but also to adapt, innovate and grow. SOTARUATA and SRINIVAS (2006) call this “emergence”, where systems co-evolve with each other and their environment.

HILL et al. (2008, p. 4) define regions as "resilient" when they are shock resistant, such that “resilient regions avoid being locked into restrictive low income level equilibria”. Resilient regions resist a situation where the shock resets the same equilibrium or results in the equilibrium (path) developing a downwards trajectory of economic development (CHRISTOPHERSON et al., 2010). In this context, building resilience requires the presence 
of resilient institutions that foster and sustain economic development. Industries in regions play a significant role as institutions which need to build adaptive economic resilience (NORTH, 1992). This is reinforced by the industry perspective of HOLM and ØSTERGAARD (2013, p. 13) who explain that "regional industrial resilience is a population concept on the adaptive capacity of a regional industry to make changes in response to a shock”.

Through innovation in building resilience, a regional system can secure a regional development economic trajectory that broadly addresses financial, social, and ecological crises affecting the region in a direction described as sustainable development (COURVISANOS, 2012, pp. 224-50). This has certainly been the experience of the New York city garment district in the case of women’s garments, where the “...local innovation system allowed variety and engagement of rival ways of similar activities, thereby unsettling the systemic features which could lead to lock in” (RANTISI, 2002, p. 599). In comparison to the entire apparel industry, which had shed almost 70,000 jobs in the period between 1975 and 2000, women's wear employment only declined from about 70,000 to about 60,000 (RANTISI, 2002, p. 588 Figure 1). As a result of a supportive role played by intermediary services, this industry went on to produce exclusive and innovative women's apparel as opposed to mass produced clothing. This industry can be considered resilient as this was adaptive (see PENDALL et al., 2010 for discussion of adaptive resilience) but not according to the equilibrium definition of resilience. A similar experience is noted by (POTTER and WATTS, 2012) in the Sheffield metals cluster (UK), where diversification of existing firms allowed their survival, and also in North Staffordshire where policy initiatives and formation of external ties with Castellon (Spain) and Sassoulo (Italy) supported regional resilience (HERVAS-OLIVER et al., 2011). NAVARRO-ESPIGARES et al. (2012) found in their 
study of 17 Spanish regions that service intensive regions were able to develop strong resilience during the 1992 and 2008 economic crises.

\section{Assessment and Evaluation of Resilience}

This section outlines the research objective of assessing and evaluating regional resilience in four different functional groups based on their regions and the industry structure, before and after potential and actual shocks. Thus, the issue is how to evaluate the pathway negotiated through such shocks. Is this a pathway to declining or rising resilience?

Assessment of regional economic resilience is difficult firstly because there are no welldefined parameters, and secondly because each researcher approaches the problem in the manner specific to their training. Therefore an approach is needed where research from different fields can be used to identify appropriate epistemological tools (MILLER et al., 2008). In this study the fields are regional development (spatial groupings), economics (industrial activity, income, and factor endowment), public policy (initiatives and incentives), and information systems (data mining and clustering algorithm). In this way, the result is likely to be most representative of the complex reality that this research seeks to evaluate in focussing on a set of diverse regions.

Regions which have access to endogenous knowledge and innovation in the manner of strong established regional innovation systems tend to do well in the face of adversity (ASHEIM and ISAKSEN, 2002; BRACZYK et al., 1998; COOKE, 2001). On the other hand, regions that rely on one principal industry or activity or group exclusively tend to be less resilient (ORMEROD, 2010). Further, those regions which enjoy vertical and horizontal linkages in their industries and institutions are considered more likely to be resilient (BERKES, 2002). In other analyses such as that of the Danish ICT sector, regions with young and small ICT service companies were found to be more resilient than those with older more rigid 
companies (HOLM and ØSTERGAARD, 2013). FINGLETON et al. (2012) used quarterly employment data from 1971 to 2009 to analyse resilience of UK regions to employment shocks and found that there were significant regional variations in recovery from employment shock. To assess the nature of regional resilience, then, the evaluation needs to examine economic activity (or income contribution) of industries within regions over periods in which shocks have occurred or threatened to occur on a national basis. This requires a broad quantitative assessment of the industry structure and the relevant income generation impact within different regional groupings; these being the four functional groups MetropolitanCore, Metropolitan-Periphery, Regional Cities, and Rural areas in this study.

A conceptual framework is required to frame the quantitative assessment. SIMMIE and MARTIN (2010) review the many concepts of regional resilience and describe how regional economies reside in a "panarchy". This is a state with complex interactions between institutions, industry, ecosystems and society. Resilience of a region then “...depends both on the longer term, region wide processes and on shorter term microscale processes and how these interact” (SIMMIE and MARTIN, 2010, p. 34). All of these interactions occur in different spatial and time frames, adding complexity to the understanding and analysis of these processes. Thus, the equilibrist approach is inadequate to explain and analyse resilience as economies are in a constant state of flux, adapting and changing with the economic, social, ecological, political and cultural environments. SIMMIE and MARTIN (2010, p. 28) take the view that resilience is a region's "adaptive ability”, as each region differs in its ability to adapt to changes and shocks of any description and magnitude. They consider that resilience does not just mean the ability to respond to the shock, but also the degree of resistance to the shock (potential or actual) in the first place. They view this ability in similar terms to SCHUMPETER's (1942) industrial mutation and creative destruction. This "adaptability” of industries in the LGAs of four functional groups is being evaluated in this study. 
The degree of adaptability of a region can be explained by its phase of interactive connectedness as defined in SIMMIE and MARTIN's (2010, p. 33) adaptation of HOLLING and GUNDERSON's (2002) and PENDALL et al.'s (2008) panarchy models. These models are descriptive and can only evaluate regions on the basis of retrospective data and as yet are not capable of predicting future trajectory of regional resilience because there is no clear time progression through the phases of these evolutionary models. Further, extant literature does not have a precise measure of the degree of adaptability. This can, however, be inferred from economic outcomes like wealth generation by industry.

Specifically, the four phases of regional resilience in the panarchy model can be explained in terms of the adaptability of a region. In SIMMIE and MARTIN's (2010) model the “conservation phase” in the adaptive cycle with high connectedness, is reflected in our model by a relatively stable pathway. When the region is in the "release phase", with high but declining connectedness and low but increasing resilience, the pathway can be more easily disrupted by external forces when connectedness decreases between the components. In this case, the region becomes more vulnerable to external shocks, unless innovation increases connectedness as in the "reorganisation phase”. Similarly in the "exploitation phase" there is low connectedness but increasing resilience and seizing of opportunities, permitting the internalisation of external forces for the good of the region. A problem associated with this "panarchy model" is that it evaluates regions and socio-economic systems from a western or developed nation perspective ignoring the existence of many traditional or "primitive" socioeconomic systems. Such "primitive” systems may have proved to be resilient over time, even though their assessment from a developed world perspective is difficult. Further, each region, despite being situated in one country with homogenous laws and socio-political systems, has unique characteristics which define its economic development trajectory, emergence and 
resilience. Therefore, four functional groups of regions, LGAs of these regions and their industrial characteristics are central to this study.

In this study the measure of adaptability in the long term is evaluated by the changes in industry structure of the four functional groups of regions. An adaptable resilient region will demonstrate change in the nature of industry over time without significant reduction in employment or income despite shocks (or perturbations). This is similar to MARTIN's (2012) study which uses output, employment, production, and services in the evaluation of regional economies in the UK for the three major recessions in 1979-83, 1990-93 and 200810. MARTIN (2012) concludes that the three recessionary shocks were different in nature and impact, yet after all three recessionary shocks employment recovery lagged behind output recovery; indicating different levels of resilience.

\section{Method and Data}

In Australia over the period 2001-2011, there have been two major shocks that affected the national economy. One was the 13-year drought that ended with the floods of early 2010 (COURVISANOS and RICHARDSON, 2011). This shock slowly accumulated over the years as the extent of the drought intensified, shifting from a normal drought cycle for the rural regions to a major unfamiliar and unknowable continuing crisis for the whole economy. On this basis, the 2006 census would strongly reflect this drought shock, as would its aftereffects in the 2011 census. The other major national shock was the short sharp GFC shock in late 2009, which saw revival by mid-2010 unto a similar growth trajectory into 2012 (COURVISANOS, 2012, p. 84 Figure 3.2). The GFC in macroeconomic quantitative terms was negotiated quickly and effectively so that economic activity could resume, but it had major structural change as some industries and regions were particularly heavily affected, such that many firms (especially in regional and rural communities) folded and some industries (especially manufacturing and tourism) suffered significant declines in activity 
through into 2011 (STIMSON, 2011, p. 38). How resilient have the industries within the four functional groups of regions in Australia been to these two shocks?

Data mining is the general method adopted in this study. It facilitates the identification of useful information within data reservoirs and involves the application of discovery algorithms to the data. Cluster analysis (clustering) is an important data mining task and a process of pattern recognition which simplifies understanding of large datasets (MARDANEH, 2012). Clustering is the task of assigning a set of objects into groups (called clusters) so that objects in the same cluster are more similar (in some sense or another) to each other than to those in other clusters (BAGIROV, 2008). Cluster analysis is used by contemporary researchers when the number of observations is large, comprising a myriad of economic and social variables (FREESTONE et al., 2003). This analysis seeks to group samples with similar characteristics and ensure maximum statistical separation from other contrasting clusters.

Cluster analysis is mainly used in information technology and data mining studies, and in a few marketing studies (CALANTONE and SAWYER, 1978; MORIARTY and VENKATESAN, 1978; SCHANINGER et al., 1980). Different algorithms are used for cluster analysis including the $k$-means algorithm. The $k$-means algorithm has only recently been used in regional studies (MARDANEH, 2012). It considers each sample (LGAs in this study) in a dataset as a point in $n$-dimensional space $\left(R^{n}\right)$ and chooses $k$ centres (also called Centroids) and assigns each point to the cluster nearest the centre. The centre is the average of all the points in the cluster, that is, its coordinates are the arithmetic mean for each dimension separately over all the points in the cluster. This algorithm is sensitive to the choice of starting points. It can converge on local minima and these local minima may be significantly different from global solutions as the number of clusters increases (BAGIROV, 2008; BAGIROV and MARDANEH, 2006). 
Using the $k$-means clustering algorithm, this study addresses the gap in understanding the combined role of location, industry structure, and income level in economic resilience. Data for this study is obtained from the ABS Census of population and housing 2001, 2006, 2011. This was sourced as industry of employment (19 categories) and individual weekly income (12 categories). NATIONAL ECONOMICS (2013) State of the Regions Report classifies LGAs under different regions as dispersed metro, independent city, knowledge base, lifestyle, resourced based, rural. Using these regions and index of LGAs in NATIONAL ECONOMICS (2013), all 558 LGAs were allocated into one of four functional groups as per NATIONAL ECONOMICS (2002) categories: Metro-Core (89), Metro-Periphery (56), Regional Cities (40), and Rural (373). This study clusters the data using the $k$-means clustering algorithm to examine in combination the location, income levels, and industry categories for economic resilience of LGAs in functional groups. In other words, the study examines whether (for example) people earning relatively high incomes are associated with any particular industries within LGAs of the specified four functional groups.

Across the three census data periods, individual weekly income is used as a proxy for economic activity. Income was initially used to separate LGAs into high and low income LGAs and not to indicate resilience. To indicate resilience, the study linked the "income level” with the industries present in a particular LGA and the employment proportion change across the three census data periods. Results are shown in Tables 2-5 as discussed below.

Specific steps taken for the data analysis are outlined below:

1. Income level data is used to separate LGAs into two categories using the following criteria:

- High income LGAs: LGAs in which the percentage of population for both " $\$ 1000$ 1999” and “\$2000 and over” income levels are above-the-median of this percentage for all LGAs. 
- Low income LGAs: LGAs in which the percentage of population for either or both “\$1000-1999” and “\$2000 and over” income levels are below-the-median of this percentage for all LGAs.

2. A dataset is created including industry of employment proportion (19 industries) for each LGA (558 LGAs in total)

3. The two above mentioned datasets are linked. This generates a combined dataset showing designation of an LGA to a high or low income LGA and its associated employment proportion across all industries.

4. LGAs are clustered by the $k$-means algorithm using the above datasets. Clustering is used to cluster LGAs rather than computing their averages. After clustering is conducted, cluster centres (Centroids) are obtained. Conducting clustering is essential to obtain these centroids. For the 2011 census, these Cluster Centroids are presented in Tables 2 to 5.

5. Two clusters of LGAs are generated. Since, using income data LGAs are separated into two categories, the employment proportion of industries under the two income categories (set out in \#1 above) is of the interest. This is obtained by clustering data into two clusters. These two clusters are:

- High Cluster: Employment proportion/industry of all high income LGAs

- Low Cluster: Employment proportion/industry of all low income LGAs

6. The assumption is that for LGAs within High Cluster, the higher proportion of employment in a particular industry would be a contributing factor to the (higher) income level of those LGAs in which the industry is located. Therefore, if employment proportion/industry in High Cluster is higher than the one in Low Cluster, that industry can be considered as "Higher industry". Whereas in the same functional group, for LGAs within Low Cluster, the higher proportion of employment in a particular industry is a contributing factor to the (lower) income level of those LGAs in which the industry is 
located. If employment proportion/industry in Low Cluster is higher than the one in High Cluster, then that industry can be considered as "Lower industry" (see Tables 2-5).

7. To compare the Cluster Centroids between High Cluster and Low Cluster, the independent-samples t-test was conducted. This test indicates whether the difference between Cluster Centroids of "High” and "Low” clusters is significant. Similar analysis has been conducted for 2006 and 2001 census data and the tables are available from the authors on application ${ }^{1}$.

\section{Analysis of Results}

With the clustering method and accompanying datasets developed, this section undertakes analysis of the results by the four regional functional groups. Initially, Table 1 shows the percentage of people within income categories in each of the four functional groups of regions over the three census periods - 2001, 2006 and 2011. For example, in the Metro-Core LGAs of census 2011, the median of people within income levels “\$1000-1999” and "\$2,000 and over” is $21.8 \%$ and $7.9 \%$ respectively; whereas, in the Metro-Periphery LGAs this same two income groupings median is $21.4 \%$ and $4.8 \%$ respectively.

\section{[INSERT Table 1 here]}

Table 2 indicates that in the Metro-Core, nine industries show higher employment proportion within High Cluster. All of these industries have lower employment proportions within Low Cluster. However, the difference (statistically significant) between these two is evident only across five industries within High Cluster. As opposed to this, for the Metro-Periphery (Table 3) there are only four "higher" industries with a high employment proportion in High Cluster. For the Metro-Core (Table 2), the "higher" industries are Information Media; Finance; Rental, Hiring and Real Estate Services; Professional, Scientific and Technical Services;

\footnotetext{
${ }^{1}$ Since we are 'averaging' many proportions, the Central Limit Theorem applies: that is, the arithmetic mean of many outcomes (in our case, proportions) of independent random variables, each with a well-defined variance, will be approximately normally distributed.
} 
Administrative and Support Services. For the Metro-Periphery (Table 3), the "higher" industries are Mining; Rental, Hiring and Real Estate Services; Professional, Scientific and Technical Services; and Education.

\section{[INSERT Tables 2 and 3 here]}

There are some similarities and differences between the Metro-Core and Metro-Periphery regional functional groups regarding employment proportion of industries in their LGAs. Rental, Hiring and Real Estate Services, as well as Professional, Scientific and Technical Services have high employment proportion within High Cluster in both regional groups, the magnitude of the latter being higher in the Metro-Core as opposed to the Metro-Periphery. In

contrast, Manufacturing, Retail Trade, and Transport in both regional groups have a significantly higher level of employment proportion within Low Cluster. The employment proportion of Mining in High Cluster is not significant in the Metro-Core, as opposed to the Metro-Periphery where this industry has significantly high employment within the above median income cluster (High Cluster).

For the Regional Cities (Table 1), the median of people within income levels “ $\$ 1,000-1,999$ ” and " $\$ 2,000$ and over" is $18.0 \%$ and $3.7 \%$ respectively. Table 4 indicates that the Regional Cities have ten industries with higher employment proportion, of which only two industries have a significantly higher level of employment within High Cluster. These are Rental, Hiring and Real Estate Services; and Professional, Scientific and Technical Services. For Rural (Table 1), the median of people within income levels of “ $\$ 1,000-1,999$ ” and " $\$ 2,000$ and over” is $15.3 \%$ and $3.1 \%$ respectively. Table 5 indicates that the Rural includes ten industries with higher employment proportion, of which seven industries have a significantly higher level of employment within High Cluster. These are Mining; Electricity, Gas, Water; Construction; Transport; Finance; Rental, Hiring and Real Estate Services; and Professional, 
Scientific and Technical Services. For Rural, the magnitude of the employment in Mining within High Cluster is much stronger than Finance.

\section{[INSERT Tables 4 and 5 here]}

A decrease in the median for percentage of people within the income categories is clearly evident progressing down the list of the four functional groups by industry in Table 1, from the Metro-Core to the Rural areas. The Appendix presents a detailed summary over the three census datasets of the average employment proportion within High and Low Clusters for each industry, as they apply across the four functional regional groupings. In the Appendix, the first set of census date columns indicate the average of employment proportions under High and Low clusters obtained from Tables 2 to 5 (for 2011 data), and similar data calculations for 2006 and 2001. For example, for the Mining industry the employment proportion in the High Cluster for the Rural LGA areas is 10.0, while in Low Cluster it is 2.0; thus the average of the two Cluster Centroids is 6.0. This average figure provides an indication of the proportion of economic activity and employment under each industry and their respective functional groups across the three census data periods. The second set of census date columns labels each industry/functional region group with " $\mathrm{H}$ " when the industry is located in the "Higher" industries section of Tables 2 to 5 (for 2011) and with "L" when the industry is located in the "Lower" industries section. This labelling is also conducted for the 2006 and 2001 datasets. Note that the non-separable industries in Tables 2-5 are identified with nonsignificant difference in employment proportion either in above or below median income clusters, and are thus labelled with " $\mathrm{N}$ " in the Appendix. The significance of this labelling will be discussed in the next section. 


\section{Patterns of Resilience}

Based on the analysis of census datasets presented in the previous section, an appreciation of resilience pathways of industries in LGAs within the four regional functional groups can now be made with the aid of the four phase resilience model (as per SIMMIE and MARTIN, 2010). The analysis examines within the last decade the resilience level of the functional group of regions and their industries in the aftermath of drought and GFC. The Appendix is used to conduct this analysis in the second set of census date columns. Functional groups and the industries with a higher employment proportion within above-median income cluster (of LGAs) are marked as $\mathrm{H}$ for High Cluster and the ones with a higher employment proportion within below-median income cluster (of LGAs) are marked as L for Low Clusters. Four functional groups of regions with 19 industry sectors for each grouping create a total of 76 regional functional groups and their relevant industries, which make up this analysis.

\section{[INSERT Table 6 here]}

Table 6 summarises the six combinations of contribution across the three periods (2001, 2006 and 2011) that are observed. These four combination patterns can be interpreted using the four phase model:

1. Functional groups of regions and industries within only High Cluster throughout the three periods. They are identified with the two patterns in Table 6 of " $\mathrm{H}-\mathrm{H}-\mathrm{H}$ " and "N-HH” over the three census periods and labelled as "Stable High" (SH1 and SH2). There are 18 functional group of regions and the relevant industries therein, which exhibit this pattern. They all indicate the continuation of high income levels throughout the decade 2001-2011. This is consistent with the macroeconomic conditions in the national economy, where Australia was able to grow throughout the long drought period and also avoid recession following the GFC. In terms of the four phase model, these groups of 
regions and their industries could be seen as remaining in the exploitation phase throughout. To reinforce the evaluation of resilient industries, examination of another independent database was considered, which supported the findings. For this, the ABS database (2011c) which consists of businesses by industry division and employment size ranges, was examined using the TableBuilder function for the periods June 2003-2006 and June 2007-2009. These two data sources provide counts of businesses with 1-19, 20199, 200+ employees, and their investigation show patterns of resilience across the same class of industries, but with no regional dimension.

As evident in Table 6, it is noteworthy that the largest number of resilient industries with a SH classification (7), are in the Rural functional group category. These seven industries are the same seven identified as "High Cluster" in the previous Analysis section of the paper. However (based on 2011 ABS Census data) only two - Mining (10.0) and Construction (8.0) - have a very strong employment proportion (see Table 5). Of the five SH classified industries that are identified as "High Cluster" in the Metro-Core, only the Professional (15.0) and Finance (7.0) service industries have a substantial 2011 employment proportion (see Table 2). Whereas the Metro-Periphery has four SH classified industries, the strongest in 2011 employment proportions being Education (8.8), followed by Professional Services (7.5), then Mining (2.6) and Real Estate (1.7) (see Table 3). Regional Cities has the least SH industries and the weakest 2011 employment proportions; Professional Services (4.8) and Real Estate (1.5) (see Table 4).

2. Functional groups of regions and industries within only Low Cluster throughout the three periods. These are identified with the three patterns "L-L-L", "N-L-L", and "L-N-L" and labelled as "Stable Low" (SL1, SL2 and SL3). There are 14 functional group of regions which with their relevant industries exhibit this pattern. They indicate very poor relative contribution to the economy throughout the decade 2001-2011. This shows that some 
functional groups and their relevant industries have found it difficult to contribute significantly through a decade of drought and GFC shocks. In terms of the four phase model, these groups of regions and industries could be seen as remaining in the release (or decline) phase throughout. Notably, seven of the 14 industries in this SL classification are in the Metro-Core, with three having substantial 2011 employment proportions: Retail (9.9), Manufacturing (7.7) and Construction (7.2) (see Table 2). A concern in terms of low resilience (SL) is that in the Metro-Periphery there is Manufacturing industry with a substantial 2011 employment proportion (12.2), while Retail registers (11.1) a "Low Cluster” for 2011 too (see Table 3). Retail also is an SL in the Regional Cities with a substantial 2011 employment proportion (12.7) (see Table 4). The two Rural SL industries, on the other hand, are public sector related industries; being Public Administration (9.8) and Health (10.8) (see Table 5).

3. Functional groups of regions and industries in High Cluster in the 2001 and 2006 censuses, then in Low Cluster in 2011 after the GFC. These are identified with the pattern “N-H-L” and labelled as 'Non-Resilient' (NR). There are three functional groups of regions and their relevant industries which exhibit this pattern, beginning in 2001 with a "N" (non-separable) and then indicating increase in their income and an exploitation phase in 2006. Then, this is followed in 2011 into the lower industries, with their poor relative contribution to the economy, indicating sharp shift through conservation to the release phase as the GFC took effect. This group show no resilience with a downward trajectory. All are Rural, with two industries having substantial 2011 employment proportions; Retail (8.5) and Education (8.5) (see Table 5). These Rural areas with such activities shift from strong to marginal, as the exploitation phase around 2006 could not be sustained after a long drought and the onset of the GFC to aggravate the already serious economic situation. 
4. Functional groups of regions and industries with higher employment proportion in both High and Low Clusters; however the difference between these two proportions is not statistically significant. These remaining functional groups of regions and their industries (41) have two or more non-separable (non-significant) periods and cannot be allocated. This includes all the functional groups for which the difference between employment proportions in High and Low Cluster is non-significant across all three periods, and are labelled as "N-N-N"; or non-significant for two periods and either High or Low for another period, labelled as "N-N-L”, "H-N-N", “L-N-N" or "N-H-N". The data for these functional groups and the relevant industries does not allow us to draw any conclusion about them.

\section{Discussion}

The patterns identified offer an appreciation for the nature of resilience in regions by industries, and thus answers the research question posed. In terms of resilience, some regions with strong industries have shown an ability to innovate and change in order to address shocks that have severe economic implications (see NAVARRO-ESPIGARES et al., 2012). Other regions have shown weakness in this crucial aspect of regional economic development (CHRISTOPHERSON et al., 2010).

Specifically, an overall detailed account on the patterns of resilience that emerge from the analysis across four functional regions over 19 industry sectors can be seen in the Appendix (resilience class membership). It shows all 76 functional groups and their relevant industries by resilience levels classed as Stable High (SH), Stable Low (SL), Non-Resilient (NR) and Non-Discriminatory (ND). Based on this, Table 6 presents in summary form the functional regions by the six resilience level classifications. In the third column in Table 6, the pattern of strong and weak resilient functional regions by industry is evident, while their employment proportions contribution were specified in the previous section. 
The strong resilient functional regions by industry are seen in SH1 and SH2 with sustained high income across the three census periods and over the two shocks (drought and GFC). Of these 18 resilient functional regions by industry (in order of frequency, with account in brackets of number in the stronger SH1); seven are Rural (2 in SH1), five are Metro-Core (all 5 in SH1), four are Metro-Periphery (3 in SH1), and two are Regional Cities (1 in SH1). Note there are 19 industry sectors for each of the four distinct functional regional groupings, thus seven of possible 19 Rural regions and their industries are deemed strongly resilient.

The impressive result that the Rural areas have registered is surprising given that the drought and GFC would be presumed to have affected small scale and agrarian-based regions most. However, breaking down the statistics in the Appendix indicates that four of functional Rural areas and their relevant industries in mining, construction, transport and utilities (electricity etc.) are all driven by the strong mining boom since the start of the $21^{\text {st }}$ century. Two other strong functional Rural areas have resilient industries of real estate and professional services; the industries which were strongly resilient across all four functional regions. Both industries may be resilient in the rural context due to inelastic demand which is relatively high in terms of employment proportions. The remaining one was in finance; an industry that would support mining and the strong rural services. A note of caution is required, with only two of seven Rural regions in the stronger SH1 (the rest have their first census period, when the drought was still relatively early, as ND); while for the Metro-Core all five are in SH1 (those being in IT, finance, as well as administrative, real estate and professional services). Further, Rural suffers from having the only three non-resilient industries; Retail, Education and Other Services, all of which need a critical mass of population to be resilient. Thus, the Rural areas and their related industries is a complex issue and does not purely reflect disadvantaged communities. 
Weak economic resilience can be seen in SL1, SL2 and SL3, where the whole period has severe negative impacts on these regions; i.e. not managing to address shocks. Of these 14 weakly resilient functional regions by industry (in order of frequency, with account in brackets of number in the statistically weakest SL1); seven are Metro-Core (all 7 in SL1), three are Metro-Periphery (2 in SL1 - manufacturing and transport), and two in both Rural and Regional City (with 1 in SL1 for both - health and agriculture respectively). This shows another surprising result, with most of the weakest regions and industries being in the MetroCore, where expectations would be that the core has the ability to be more resilient. The level of complexity in such large regions, as noted in SIMMIE and MARTIN (2010), may induce negative spillovers from linked industries; this can be noted in six of these low resilient core regions where it relates to agriculture, manufacturing, construction, transport, utilities and retail industries (remaining one is "other”).

Most of the Metro-Periphery and the Regional Cities functional regions are identified statistically as Non-Discriminatory (ND), allowing little analysis. For the identified resilient industries that are common in the Metro-Periphery and the Rural regional clusters, there is real estate and professional - both which are resilient across all four functional regions anyway, possibly due to strong inelastic demand. Thus, only remaining are the two resilient Metro-Periphery regions of mining (spillover from Rural) and education and training (supported by higher education institutions on city edges). JAIN and COURVISANOS (2009) explain that in Metro-Periphery regions the lack of internal strength arising from limited (or no) diversity in export base activities and low scale of operations are major hindrance to greater number of regions being resilient. There is also an indication that this is a problem for the Rural areas as well (EVERSOLE and MARTIN, 2006), which also includes all four non-resilient (NR) regions and industries. 
Focusing on industries and their patterns across the four functional groupings elicits further insights. Most notable are the six strongly resilient industries across all discriminatory regions; these being Mining, Finance, Real Estate, Professional Services, and IT. All reflect strong effective demand arising from Australia's competitive advantage based on exports and commercial services (HENRY, 2013), as well as Australia’s ability through demand stimulus and regulation to navigate across the GFC without a recession (WETTENHALL, 2011). On the other hand, low resilient industries reflect industries that are on the decline in Australia (Manufacturing and Agriculture), and public sector based industries that are under demand pressure from public austerity programs by all levels and political types of governments (Public Administration and Health). The three large infrastructure-based industries of Utilities, Construction and Transport depict shifting patterns across the regions, with all three registering SL in Metro-Core and SH in Rural. The Rural strength can be seen as related to the success of mining in rural areas of Australia and this industry's need for sophisticated infrastructure to operate successfully; whereas the Metro-Core does not directly benefit at the same level of intensity given the already long established infrastructure in the few major cities of Australia.

Final observations on the shifting character of industries across regions relate to the large Education sector (consisting of primary, secondary and tertiary) with strong resilience in the Metro-Periphery with substantial employment proportion. With large population growth in the periphery, this sector has boomed but may come under threat with increasing austerity from the public budget (JAIN and COURVISANOS, 2009). This can be contrasted with nonresiliency in the Rural areas with their lack of population. Also note the strong resilience (SH) of Administrative Services in the Metro-Core compared to low resilience (SL) in the Metro-Periphery. The employment proportions are rather low in both regional groupings, but 
the nature of large extensive central CBDs in capital cities that make up Australia's MetroCore reflects this resilience.

Two limitations of this study provide a roadmap for deeper investigation into regional resilience in Australia. One is that only three census data points $(2001,2006,2011)$ are available to be accessed and thus build the database for clustering. This is a limited time horizon with only two shocks in snapshot data points to examine the resilience of regions by industry. To overcome this limitation, the study needs to extend back in time to cover census periods that take in the 1989-92 recession. This requires the statistical data from ABS to reach back into the late 1980s. Given the number of LGAs and their respective industrial sectors, preparation of the data concordance will be a big task. Into the future, it would also be useful to elicit effects from the end of the construction phase of the mining boom (using 2016 census data when it becomes available). Both the early 1980s recession and end of mining investment can be seen as significant shocks to the national economy. This is especially the case for the functional Rural regions that have been resilient due to the strong investment in construction for mining in the whole of three census periods studied.

Reasons for the strength and weakness identified above need to be appreciated before policy and practice can be advocated. This identifies the second limitation in that quantitative analysis alone cannot provide such answers. An understanding of resilience requires in-depth qualitative investigation of regions, their industries and the nature of innovation (or lack thereof) that is required to build resilience (COURVISANOS, 2012). Work on this aspect has already begun, with the authors identifying the most and least resilient functional groups by industry from the Appendix and conducting interviews and focus groups in these communities. 


\section{Conclusion}

Given that shocks to a region cannot be predicted (NORRIS et al., 2008, p. 132), broad resilience strategies need to be developed on the basis of first identifying the character (or nature) of resilience in terms of strong and weak resilience pathways (see MARTIN, 2012). Adopting the conceptual framework of panarchy in this paper enables an appreciation of resilience to which causal mechanisms can be pursued that form the basis for such strategies. This paper has taken the first step of identifying such resilience pathways for Australia's regions by functional groups and their industries. Further the $k$-means clustering approach is a unique and effective research method that enables transferable knowledge to other regions and their industries on the nature of economic resilience due to adversity (shocks) and related social activity. This novel empirical methodology of studying resiliency provides a new tool thus far not utilised for this purpose.

Shocks across time, potential and actual, and pathways negotiated by different functional regions (Metro-Core, Metro-Periphery, Regional Cities, Rural) across the whole spectrum of industries are the essence of the analysis in this paper. Here, the implications are for the way researchers understand patterns of resilience in the context of shocks over a period of time. Such nature of resilience has application outside the Australian situation, by identifying empirical patterns based on the four phase model (SIMMIE and MARTIN, 2010). Adaptability through broad resilience strategies (known as "building resilience”) developed in public and private policy mediums arise out of deep understanding of causal mechanisms, which is the function of ongoing deeper research in Australian functional regions coming out of this macroeconomic study. Thus this paper provides unique empirical evidence for SIMMIE and MARTIN'S (2010) resiliency model using data from 2001 to 2011, over three census periods, for an entire continent as opposed to a case study of a single region. 
Finally this paper by extending the empirical discussion of regional resilience to Australia, an entire continent heretofore ignored by resilience literature, fills a void in extant literature. Regional resilience, or its lack thereof, and the factors affecting it are a global problem. Understanding the variation in the factors affecting resilience between regions can surely benefit policy makers by providing a deeper understanding of the specific issues in each region rather than using general data and findings from elsewhere.

\section{References}

ABS (Australian Bureau of Statistics) (2001a) LGA by INDP, 1 Digit level, Counting: Persons, Place of Usual Residence, Census of Population and Housing, ABS TableBuilder. ABS (2001b) LGA by INCP, Counting: Persons, Place of Usual Residence, Census of Population and Housing, ABS TableBuilder.

ABS (2006a) LGA by Industry of Employment (ANZSIC06),(IND06P), Counting: Persons, Place of Usual Residence, Census of Population and Housing, ABS TableBuilder.

ABS (2006b) LGA by Individual Income (weekly) (INCP), Counting: Persons, Place of Usual Residence, Census of Population and Housing, ABS TableBuilder.

ABS (2011a) LGA by INDP, 1 Digit Level, Counting: Persons, Place of Usual Residence, Census of Population and Housing, ABS TableBuilder.

ABS (2011b) LGA by INCP, Counting: Persons, Place of Usual Residence, Census of Ppopulation and Hhousing, ABS TableBuilder.

ABS (2011c) Counts of Australian Businesses including Entries and Exits, Jun 2003 to Jun 2006 \& Jun 2007 to Jun 2009, Catalogue No. 8165.0.

ASHEIM B. and ISAKSEN A. (2002) Regional innovation systems: the integrating of local sticky and global ubiquitous knowledge, The Journal of Technology Transfer 27, 77-86.

BAGIROV A. M. (2008) Modified global k-means algorithm for minimum sum-of-squares clustering problems, Pattern Recognition 41, 3192-9.

BAGIROV A. M. and MARDANEH K. (2006) Modified global k-means algorithm for clustering in gene expression data sets, in BODEN M. and BAILEY T. L. (Eds) 2006 Workshop on Intelligent Systems for Bioinformatics (WISB 2006), pp. 23-8. Australian Computer Society, Hobart, TAS.

BERKES F. (2002) Cross-scale institutional linkages: perspectives from the bottom up, in OSTROM E, DIETZ T., DOLSAK N., STERN P. C., STONACH S. and WEBBER E. U. (Eds) The Drama of the Commons, pp. 293-321. National Academy Press, Washington DC.

BRACZYK H. J., COOKE P. N. and HEIDENREICH M. (1998) Regional Innovation Systems: The Role of Governances in a Globalised World. Routledge, London.

BRISTOW G. (2010) Resilient regions: re-'place'ing regional competitiveness, Cambridge Journal of Regions, Economy and Society 3, 153-67.

BRISTOW G. and HEALY A. (2013) Regional resilience: an agency perspective, Regional Studies ahead-of-print, 1-13.

CALANTONE R. J. and SAWYER A. G. (1978) The stability of benefit segments, Journal of Marketing Research 15, 395-404.

CELLINI R. and TORRISI G. (2014) Regional resilience in Italy: a very long-run analysis, Regional Studies ahead-of-print, 1-18. 
CHAPPLE K. and LESTER T. W. (2010) The resilient regional labour market? the US case, Cambridge Journal of Regions, Economy and Society 3, 85-104.

CHRISTOPHERSON S., MICHIE J. and TYLER P. (2010) Regional resilience: theoretical and emrpirical perspectives, Cambridge Journal of Regions, Economy and Society 3, 310.

COOKE P. (2001) Regional innovation systems, clusters, and the knowledge economy, Industrial and Corporate Change 10, 945-74.

COURVISANOS J. (2012) Cycles, Crises and Innovation: Path to Sustainable Development - A Kaleckian-Schumpeterian Synthesis. Edward Elgar, Cheltenham, UK.

COURVISANOS J. and RICHARDSON C. (2011) Economic modelling of climate change and water in a regulated river basin, Journal of Economic And Social Policy 14, Article 7.

EDWARDS B., GRAY M. and HUNTER B. (2009) A sunburnt country: the economic and financial impact of drought on rural and regional families in Australia in an era of climate change, Australian Journal of Labour Economics 12, 109.

EVERSOLE R. and MARTIN J. (2006) Jobs in the bush: global industries and inclusive rural development, Social Policy \& Administration 40, 692-704.

FINGLETON B., GARRETSEN H. and MARTIN R. (2012) Recessionary shocks and regional employment: evidence on the resilience of UK regions, Journal of Regional Science 52, 109-33.

FREESTONE R., MURPHY P. and JENNER A. (2003) The functions of Australian towns revisited, Tijdschrift voor Economische en Sociale Geografie 94, 188-204.

HENRY K. (2013) Macroeconomic policy challenges in the Asian century, The Economic and Labour Relations Review 24, 150-60.

HERVAS-OLIVER J.-L., JACKSON I. and TOMLINSON P. R. (2011) May the ovens never grow cold': regional resilience and industrial policy in the North Staffordshire ceramics industrial district - with lessons from Sassoulo and Castellon, Policy Studies 32, 377-95.

HILL E., WIAL H. and WOLMAN H. (2008) Exploring regional economic resilience, Working Paper, Institute of Urban and Regional Development, No. 2008,04. UC Berkely, Institute of Urban and Regional Development (IURD).

HOLLING C. S. and GUNDERSON L. H. (2002) Resilience and adaptive cycles, in GUNDERSON L. and HOLLING C. S. (Eds) Panarchy: Understanding Transformations in Human and Natural Systems, pp. 25-62. Island Press, Washington DC

HOLM J. R. and ØSTERGAARD C. R. (2013) Regional employment growth, shocks and regional industrial resilience: a quantitative analysis of the Danish ICT sector, Regional Studies ahead-of-print, 1-18.

HORRIDGE M., MADDEN J. and WITTWER G. (2005) The impact of the 2002-2003 drought on Australia, Journal of Policy Modeling 27, 285-308.

JAIN A. and COURVISANOS J. (2009) Urban growth centres on the periphery: ad hoc policy vision and research neglect, Australasian Journal of Regional Studies 15, 3-26.

LIM G., NGUYEN V. and CHUA C. (2014) Review of the Australian economy 2013-14: the age of austerity? Australian Economic Review 47: 1-12.

MARDANEH K. (2012) A study of population change via clustering of australian regional areas: An optimisation approach, Australasian Journal of Regional Studies 1.

MARTIN R. (2012) Regional economic resilience, hysteresis and recessionary shocks, Journal of Economic Geography 12, 1-32.

MILLER T. R., BAIRD T. D., LITTLEFIELD C. M., KOFINAS G., F. CHAPIN III and REDMAN. C. L. (2008) Epistemological pluralism: reorganizing interdisciplinary research, Ecology and Society 13, 46 [online].

MORIARTY M. and VENKATESAN M. (1978) Concept evaluation and market segmentation, Journal of Marketing 42, 82-6. 
NATIONAL ECONOMICS (2002) 2002 State of the Regions Report. NIER, Clifton Hill, VIC.

NATIONAL ECONOMICS (2013) 2012-13 State of the Regions Report. NIER, Clifton Hill, Vic.

NAVARRO-ESPIGARES J. L., MARTÍN-SEGURA J. A. and HERNÁNDEZ-TORRES E. (2012) The role of the service sector in regional economic resilience, The Service Industries Journal 32, 571-90.

NORRIS F. H., STEVENS S. P., PFEFFERBAUM B., WYCHE K. F. and PFEFFERBAUM R. L. (2008) Community resilience as a metaphor, theory, set of capacities, and strategy for disaster readiness, American journal of community psychology 41, 127-50.

NORTH D. C. (1992) Institutions and economic theory, American Economist 36, 3-6.

ORMEROD P. (2010) Resilience after local economic shocks, Applied Economics Letters 17, 503-7.

PENDALL R., FOSTER K. A. and COWELL M. (2008) Resilience and Regions: Building Understanding of the Metaphor. Mimeo Institute of Urban and Regional Development. Cornell University, Ithaca, NY.

PENDALL R., FOSTER K. A. and COWELL M. (2010) Resilience and regions: building understanding of the metaphor, Cambridge Journal of Regions, Economy and Society 3, 7184.

PIKE A., DAWLEY S. and TOMANEY J. (2010) Resilience, adaptation and adaptability, Cambridge Journal of Regions, Economy and Society 3, 59-70.

POTTER A. and WATTS H. D. (2012) Revisiting Marshall's agglomeration economies: technological relatedness and the evolution of the Sheffield metals cluster, Regional Studies ahead-of-print, $1-21$.

RANTISI N. M. (2002) The local innovation system as a source of 'variety': openness and adaptability in New York City's garment district, Regional Studies 36, 587-602.

SCHANINGER C. M., LESSIG V. P. and PANTON D. B. (1980) The complementary use of multivariate procedures to investigate nonlinear and interactive relationship between personality and product usage, Journal of Marketing Research 17, 119-24.

SCHUMPETER J. A. (1942) Capitalism, Socialism and Democracy. McGraw Hill, New York.

SIMMIE J. and MARTIN R. (2010) The economic resilience of regions: towards an evolutionary approach, Cambridge Journal of Regions, Economy and Society 3, 27-43.

SOTARAUTA M. and SRINIVAS S. (2006) Co-evolutionary policy processes: understanding innovative economies and future resilience, Futures 38, 312-36.

STIMSON R. J. (2011) Australia's changing economic geography revisited, The Australasian Journal of Regional Studies 17, 22-45.

TALEB N. N. (2007) Black swans and the domains of statistics, The American Statistician 61, 198-200.

TREADO C. D. (2010) Pittsburgh's evolving steel legacy and the steel technology cluster, Cambridge Journal of Regions, Economy and Society 3, 105-20.

WETTENHALL R. (2011) Global financial crisis: the Australian experience in international perspective, Public Organization Review 11, 77-91. 
Table 1: Percentage of people within income categories in each functional group of regions, 2001-2011

\begin{tabular}{|c|c|c|c|c|c|c|c|c|c|c|c|c|}
\hline \multirow[t]{3}{*}{ Functional group } & \multicolumn{3}{|c|}{$\begin{array}{c}\text { Median for } \\
\text { percentage of } \\
\text { people within the } \\
\text { income category }\end{array}$} & \multicolumn{3}{|c|}{$\begin{array}{c}\text { Shares of people } \\
\text { within the income } \\
\text { category }\end{array}$} & \multicolumn{3}{|c|}{$\begin{array}{c}\text { Median for } \\
\text { percentage of people } \\
\text { within the income } \\
\text { category }\end{array}$} & \multicolumn{3}{|c|}{$\begin{array}{c}\text { Shares of people } \\
\text { within the income } \\
\text { category }\end{array}$} \\
\hline & \multicolumn{6}{|c|}{$\$ 1,000-\$ 1,999$} & \multicolumn{6}{|c|}{$\$ 2,000$ and over } \\
\hline & 2001 & 2006 & 2011 & 2001 & 2006 & 2011 & 2001 & 2006 & 2011 & 2001 & 2006 & 2011 \\
\hline Metro-Core & 8.3 & 16.9 & 21.8 & 4948 & 10833 & 15300 & 4.6 & 4.7 & 7.9 & 3462 & 3386 & 6096 \\
\hline Metro-Periphery & 6.4 & 15.0 & 21.4 & 5173 & 11990 & 19368 & 2.1 & 2.3 & 4.8 & 2474 & 2334 & 4979 \\
\hline Regional Cities & 5.8 & 12.5 & 18.0 & 2736 & 5855 & 9283 & 2.0 & 1.8 & 3.7 & 1043 & 978 & 2264 \\
\hline Rural Areas & 4.4 & 9.8 & 15.3 & 545 & 896 & 1657 & 2.0 & 1.5 & 3.1 & 283 & 158 & 446 \\
\hline
\end{tabular}

*The income categories for 2001 data are ‘\$1,000-1,499’ and ‘\$1,500 and over’ (ABS, 2001). 
Table 2: Employment level of industries within above and below median income clusters: Metro-core LGAs-2011

\begin{tabular}{|c|c|c|c|c|}
\hline \multirow[b]{2}{*}{ Industry } & \multicolumn{2}{|c|}{$\begin{array}{l}\text { Cluster of LGAs: Employment } \\
\text { proportion in the industry } \\
\text { (Cluster Centroids) }\end{array}$} & \multicolumn{2}{|c|}{$\begin{array}{c}\text { Test of } \\
\text { independence\# }\end{array}$} \\
\hline & $\begin{array}{l}\text { Employment } \\
\text { proportion in } \\
\text { above median } \\
\text { income cluster } \\
\text { (High Cluster) }\end{array}$ & $\begin{array}{l}\text { Employment } \\
\text { proportion in } \\
\text { below } \\
\text { median } \\
\text { income } \\
\text { cluster (Low } \\
\text { Cluster) }\end{array}$ & $t$ & $d f$ \\
\hline \multicolumn{5}{|c|}{$\begin{array}{c}\text { Higher industries (Significantly high employment proportion in above median } \\
\text { income cluster) }\end{array}$} \\
\hline Information Media & 3.5 & 1.8 & 5.4 & $44.0 * * *$ \\
\hline Finance & 7.0 & 4.0 & 4.5 & $50.1 * * *$ \\
\hline Rental, Hiring and Real Estate Services & 2.1 & 1.7 & 3.3 & $86.9 * * *$ \\
\hline Professional, Scientific and Technical Services & 15.0 & 7.8 & 8.9 & $81.0 * * *$ \\
\hline Administrative and Support Services & 3.5 & 3.2 & 1.9 & $82.0 *$ \\
\hline \multicolumn{5}{|c|}{$\begin{array}{c}\text { Lower industries (Significantly high employment proportion in below median } \\
\text { income cluster) }\end{array}$} \\
\hline Agriculture, Forestry and Fishing & 0.3 & 2.6 & -2.9 & $53.0 * *$ \\
\hline Manufacturing & 5.0 & 7.7 & -5.2 & $72.5^{* * *}$ \\
\hline Electricity, Gas, Water & 0.8 & 1.2 & -4.1 & $78.6^{* * *}$ \\
\hline Construction & 5.5 & 7.2 & -4.0 & $76.9 * * *$ \\
\hline Retail Trade & 8.1 & 9.9 & -5.0 & $86.6 * * *$ \\
\hline Transport & 2.9 & 4.5 & -5.0 & $75.6 * * *$ \\
\hline Other Services & 2.9 & 3.4 & -3.5 & $86.9 * * *$ \\
\hline \multicolumn{5}{|c|}{$\begin{array}{c}\text { Non-separable industries (Non-significant difference in employment proportion in either above or } \\
\text { below median income clusters) }\end{array}$} \\
\hline Mining & 1.8 & 1.3 & 0.9 & 57.3 \\
\hline Wholesale Trade & 4.0 & 3.9 & 0.6 & 76.9 \\
\hline Education & 8.9 & 8.4 & 1.0 & 86.9 \\
\hline Arts and Recreation Services & 2.1 & 1.8 & 1.1 & 74.5 \\
\hline Accommodation & 6.5 & 7.3 & -1.6 & 85.3 \\
\hline Public Administration & 6.2 & 7.5 & -1.3 & 67.2 \\
\hline Health Care and Social Assistance & 11.4 & 12.0 & -1.0 & 85.0 \\
\hline
\end{tabular}

Test of independence* $\mathrm{p}<.05^{* *} \mathrm{p}<0.01{ }^{* * *} \mathrm{p}<0.001$

\#Note: The significance refers to the difference between values in "High Cluster" and "Low Cluster" for a particular industry. 
Table 3: Employment level of industries within above and below median income clusters: Metro-periphery LGAs-2011

\begin{tabular}{|c|c|c|c|c|}
\hline \multirow[b]{2}{*}{ Industry } & \multicolumn{2}{|c|}{$\begin{array}{l}\text { Cluster of LGAs: } \\
\text { Employment } \\
\text { proportion in the } \\
\text { industry (Cluster } \\
\text { Centroids) }\end{array}$} & \multicolumn{2}{|c|}{$\begin{array}{c}\text { Test of } \\
\text { independence }\end{array}$} \\
\hline & $\begin{array}{c}\text { Employ- } \\
\text { ment } \\
\text { proportion } \\
\text { in above } \\
\text { median } \\
\text { income } \\
\text { cluster } \\
\text { (High } \\
\text { Cluster) }\end{array}$ & $\begin{array}{l}\text { Employ- } \\
\text { ment } \\
\text { proportion } \\
\text { in below } \\
\text { median } \\
\text { income } \\
\text { cluster } \\
\text { (Low } \\
\text { Cluster) }\end{array}$ & $t$ & $d f$ \\
\hline \multicolumn{3}{|c|}{$\begin{array}{c}\text { Higher industries (Significantly high employment proportion in above median } \\
\text { income cluster) }\end{array}$} & & \\
\hline Mining & 2.6 & 0.6 & 5.2 & $24.6 * * *$ \\
\hline Rental, Hiring and Real Estate Services & 1.7 & 1.4 & 4.1 & $53.5^{* * *}$ \\
\hline Professional, Scientific and Technical Services & 7.5 & 5.7 & 2.6 & $50.6 * *$ \\
\hline Education & 8.8 & 7.0 & 4.3 & $31.6 * * *$ \\
\hline \multicolumn{3}{|c|}{$\begin{array}{c}\text { Lower industries (Significantly high employment proportion in below median } \\
\text { income cluster) }\end{array}$} & & \\
\hline Manufacturing & 9.2 & 12.2 & -4.5 & $53.4 * * *$ \\
\hline Retail Trade & 10.4 & 11.1 & -2.6 & $53.3 * *$ \\
\hline Transport & 4.9 & 6.0 & -2.0 & $52.1 *$ \\
\hline Administrative and Support Services & 3.0 & 3.4 & -2.2 & $53.9 * *$ \\
\hline \multicolumn{5}{|c|}{$\begin{array}{c}\text { Non-separable industries (Non-significant difference in employment proportion in either above or } \\
\text { below median income clusters) }\end{array}$} \\
\hline Construction & 10.0 & 9.1 & 0.8 & 47.7 \\
\hline Public Administration & 6.7 & 6.1 & 1.2 & 49.4 \\
\hline Health Care and Social Assistance & 11.1 & 11.0 & 0.2 & 42.8 \\
\hline Arts and Recreation Services & 1.5 & 1.3 & 1.2 & 50.5 \\
\hline Other Services & 4.0 & 3.9 & 0.5 & 37.6 \\
\hline Agriculture, Forestry and Fishing & 0.6 & 1.6 & -1.9 & 35.9 \\
\hline Electricity, Gas, Water & 1.1 & 1.2 & -0.3 & 52.8 \\
\hline Wholesale Trade & 4.4 & 4.9 & -1.5 & 41.0 \\
\hline Accommodation & 5.2 & 5.6 & -1.6 & 44.2 \\
\hline Information Media & 1.5 & 1.6 & -0.2 & 41.5 \\
\hline Finance & 3.4 & 3.5 & -0.1 & 48.9 \\
\hline
\end{tabular}

${ }^{*} \mathrm{p}<.05 * * \mathrm{p}<0.01 * * * \mathrm{p}<0.001$ 
Table 4: Employment level of industries within above and below median income clusters: Regional cities LGAs-2011

\begin{tabular}{|c|c|c|c|c|}
\hline \multirow[b]{2}{*}{ Industry } & \multicolumn{2}{|c|}{$\begin{array}{l}\text { Cluster of LGAs: } \\
\text { Employment } \\
\text { proportion in the } \\
\text { industry (Cluster } \\
\text { Centroids) }\end{array}$} & \multicolumn{2}{|c|}{$\begin{array}{c}\text { Test of } \\
\text { independence }\end{array}$} \\
\hline & $\begin{array}{l}\text { Employ- } \\
\text { ment } \\
\text { proportion } \\
\text { in above } \\
\text { median } \\
\text { income } \\
\text { cluster } \\
\text { (High } \\
\text { Cluster) }\end{array}$ & $\begin{array}{l}\text { Employ- } \\
\text { ment } \\
\text { proportion } \\
\text { in below } \\
\text { median } \\
\text { income } \\
\text { cluster } \\
\text { (Low } \\
\text { Cluster) }\end{array}$ & $t$ & $d f$ \\
\hline \multicolumn{5}{|c|}{$\begin{array}{c}\text { Higher industries (Significantly high employment proportion in above median } \\
\text { income cluster) }\end{array}$} \\
\hline Rental, Hiring and Real Estate Services & 1.5 & 1.3 & -4.7 & $22.1 * * *$ \\
\hline Professional, Scientific and Technical Services & 4.8 & 3.6 & 2.7 & $16.7 * *$ \\
\hline \multicolumn{5}{|c|}{$\begin{array}{c}\text { Lower industries (Significantly high employment proportion in below median } \\
\text { income cluster) }\end{array}$} \\
\hline Agriculture, Forestry and Fishing & 0.8 & 3.8 & -4.7 & $32.7 * * *$ \\
\hline Retail Trade & 10.8 & 12.7 & -4.7 & $22.1 * * *$ \\
\hline Accommodation & 6.4 & 7.6 & -2.9 & $38.9 * * *$ \\
\hline \multicolumn{5}{|c|}{$\begin{array}{c}\text { Non-separable industries (Non-significant difference in employment proportion in either above or } \\
\text { below median income clusters) }\end{array}$} \\
\hline Mining & 6.5 & 2.4 & 1.6 & 15.0 \\
\hline Construction & 8.7 & 8.3 & 0.6 & 20.0 \\
\hline Transport & 4.5 & 4.2 & 0.9 & 27.1 \\
\hline Information Media & 1.1 & 1.0 & 0.8 & 20.6 \\
\hline Finance & 2.2 & 2.0 & 0.6 & 17.3 \\
\hline Administrative and Support Services & 3.1 & 3.0 & 0.2 & 26.8 \\
\hline Public Administration & 7.9 & 6.5 & 1.0 & 14.8 \\
\hline Other Services & 4.1 & 3.9 & 1.0 & 17.8 \\
\hline Manufacturing & 9.4 & 9.6 & -0.1 & 22.3 \\
\hline Electricity, Gas, Water & 1.3 & 1.7 & -1.4 & 32.2 \\
\hline Wholesale Trade & 2.8 & 2.9 & -0.5 & 38.2 \\
\hline Education & 8.0 & 8.2 & -0.3 & 25.9 \\
\hline Health Care and Social Assistance & 12.3 & 13.5 & -1.4 & 21.8 \\
\hline Arts and Recreation Services & 1.0 & 1.1 & -0.5 & 24.0 \\
\hline
\end{tabular}

${ }^{*} \mathrm{p}<.05 * * \mathrm{p}<0.01 * * * \mathrm{p}<0.001$ 
Table 5: Employment level of industries within above and below median income clusters: Rural LGAs-2011

\begin{tabular}{|c|c|c|c|c|}
\hline \multirow[b]{2}{*}{ Industry } & \multicolumn{2}{|c|}{$\begin{array}{l}\text { Cluster of LGAs: } \\
\text { Employment } \\
\text { proportion in the } \\
\text { industry (Cluster } \\
\text { Centroids) }\end{array}$} & \multicolumn{2}{|c|}{$\begin{array}{c}\text { Test of } \\
\text { independence }\end{array}$} \\
\hline & $\begin{array}{l}\text { Employ- } \\
\text { ment } \\
\text { proportion } \\
\text { in above } \\
\text { median } \\
\text { income } \\
\text { cluster } \\
\text { (High } \\
\text { Cluster) }\end{array}$ & $\begin{array}{l}\text { Employ- } \\
\text { ment } \\
\text { proportion } \\
\text { in below } \\
\text { median } \\
\text { income } \\
\text { cluster } \\
\text { (Low } \\
\text { Cluster) }\end{array}$ & $t$ & $d f$ \\
\hline \multicolumn{3}{|c|}{$\begin{array}{c}\text { Higher industries (Given their high employment proportion in above median } \\
\text { income cluster) }\end{array}$} & & \\
\hline Mining & 10.0 & 2.0 & 6.8 & $151.6 * * *$ \\
\hline Electricity, Gas, Water & 1.2 & 0.9 & 2.0 & $246.9 *$ \\
\hline Construction & 8.0 & 6.1 & 5.1 & $235.6 * * *$ \\
\hline Transport & 4.6 & 3.9 & 3.2 & $305.2 * * *$ \\
\hline Finance & 1.2 & 1.0 & 2.0 & $272.3^{*}$ \\
\hline Rental, Hiring and Real Estate Services & 1.0 & 0.6 & 4.2 & $224.2^{* * *}$ \\
\hline Professional, Scientific and Technical Services & 2.8 & 2.2 & 3.4 & $228.3 * * *$ \\
\hline \multicolumn{3}{|c|}{$\begin{array}{c}\text { Lower industries (Given their high employment proportion in below median } \\
\text { income cluster) }\end{array}$} & & \\
\hline Retail Trade & 7.5 & 8.5 & -2.8 & $330.7 * *$ \\
\hline Public Administration & 7.3 & 9.8 & -2.8 & $329.0 * * *$ \\
\hline Education & 7.6 & 8.5 & -2.7 & $338.1^{* *}$ \\
\hline Health Care and Social Assistance & 7.5 & 10.8 & -7.7 & $310.3 * * *$ \\
\hline Arts and Recreation Services & 0.7 & 1.1 & -2.5 & $338.3 * *$ \\
\hline Other Services & 3.1 & 4.4 & -4.9 & $269.4 * * *$ \\
\hline \multicolumn{5}{|c|}{$\begin{array}{c}\text { Non-separable industries (Non-significant difference in employment proportion in either above or } \\
\text { below median income clusters) }\end{array}$} \\
\hline Wholesale Trade & 2.5 & 2.3 & 0.4 & 308.8 \\
\hline Accommodation & 6.4 & 5.7 & 1.8 & 250.7 \\
\hline Information Media & 0.5 & 0.4 & 0.4 & 286.5 \\
\hline Agriculture, Forestry and Fishing & 17.5 & 19.7 & -1.3 & 273.2 \\
\hline Manufacturing & 5.9 & 6.2 & -0.4 & 317.7 \\
\hline Administrative and Support Services & 2.1 & 2.3 & -0.6 & 358.9 \\
\hline
\end{tabular}

${ }^{*} \mathrm{p}<.05{ }^{* *} \mathrm{p}<0.01 * * * \mathrm{p}<0.001$ 
Table 6: Resilience Levels of Functional Regions and their industries

\begin{tabular}{|l|c|l|}
\hline & $\begin{array}{c}\text { Periods 2001- } \\
\mathbf{2 0 0 6 - 2 0 1 1}\end{array}$ & Industry/Functional Region Patterns \\
\hline 1.Stable High (SH1) & H-H-H & MC:5; MP:3; RC:1; RU:2 \\
\hline 2.Stable High (SH2) & N-H-H & MC:0; MP:1; RC:1; RU:5 \\
\hline 3.Stable Low (SL1) & L-L-L & MC:7; MP:2; RC:1; RU:1 \\
\hline 4.Stable Low (SL2) & N-L-L & MC:0; MP:0; RC:0; RU:1 \\
\hline 5.Stable Low (SL3) & L-N-L & MC:0; MP:1; RC:1; RU:0 \\
\hline 6. Non-Resilient (NR) & N- $\underline{\text { H-L }}$ - & MC:0; MP:0; RC:0; RU:3 \\
\hline
\end{tabular}

Functional Groups acronyms: Metro-Core (MC); Metro-Periphery (MP); Regional Cities (RC); Rural (RU)

Cluster acronyms: H: High Cluster; L: Low Cluster; N: Non-separable industries (in which the employment proportion difference in 'High' and 'Low' Cluster is non-significant)

Note: The remaining functional regions and their industries (41) have two or more non-separable (nonsignificant) periods and they cannot be allocated. 